\title{
Reticulate acropigmentation of Kitamura
}

INSERM

\section{Source}

INSERM. (1999). Orphanet: an online rare disease and orphan drug data base. Reticulate acropigmentation of Kitamura. ORPHA:178307

A rare, genetic, hyperpigmentation of the skin disease characterized by childhood to adulthood-onset of reticulate, slightly depressed, sharply demarcated, brown, macular skin lesions without hypopigmentation, affecting the dorsa of the hands and feet, and, occasionally, progressing to involve limbs, neck, forehead and/or trunk. Interrupted dermatoglyphics and palmoplantar pits may be additionally observed. Histologically, hyperpigmented lesions show slightly elong ated and thinned rete ridges, mild hyperkeratosis without parakeratosis and absence of incontinentia pigmenti. 